\title{
17: 71509014-71513251
}

National Cancer Institute

\section{Source}

National Cancer Institute. 17: 71509014-71513251. NCI Thesaurus. Code C41932.

Physical location of CDK3_Gene 